\title{
Solitary osteochondroma of the Scapula: an uncommon localization
}

\author{
Sara El rharras ${ }^{*}$, Rachid Farah ${ }^{1}$, Hanane El Haoury ${ }^{2}$, Halim Saidi ${ }^{2}$ and Imane El Bouchti ${ }^{1}$ \\ ${ }^{1}$ Department of Rheumatology, Arrazi Hospital, Mohammed VI Universitary Center, Marrakech, Morocco \\ ${ }^{2}$ Department of Orthopaedic Surgery, Arrazi Hospital, Mohammed VI Universitary Center, Marrakech, Morocco
}

\section{Introduction}

Osteochondroma or exostosis is the most common benign bone tumors. They are usually located in long bones metaphysis. Location in flat bone like scapula is thus very uncommon, we report a new case with literature review.

\section{Case presentation}

A 16-year-old female patient who had been suffering from pain in her right shoulder for 4 years, with "clunking" during active movements. No antecedent history of trauma or similar family cases were reported. Physical examination revealed winging of scapula's inferior and medial part in both static postion and dynamic movements abduction and antepulsion. It did not increase as the patient did push against the wall implying that the thoracic long nerve was not damaged. No bony mass was felt. Glenohumeral joint movement was respected with neither signs of acromial conflict nor amyotophy of the supra-spinatus and infra-spinatus muscles. Radiographs of profile shoulder showed a large bony outgrowth arising from the medial side of scapula at the height of the 4th right rib causing 3rd intercostal space enlargement (figure 1). Scapula profil radiograph highlighted the pedunculated aspect of the bony lesion (Figure 2). The CT scan confirmed that the lesion started from the ventral scapula in continuity with the cortical without signs of ruptures or invasion of soft tissues (Figure 3). Total surgical resection was performed and led to relief of symptoms. Anatomopathological examination confirmed the diagnosis of osteochondroma. At 6 months follow-up, there was no tumor recurrence, scapular winging regressed as well as pain (Figures $4,5,6$ ).

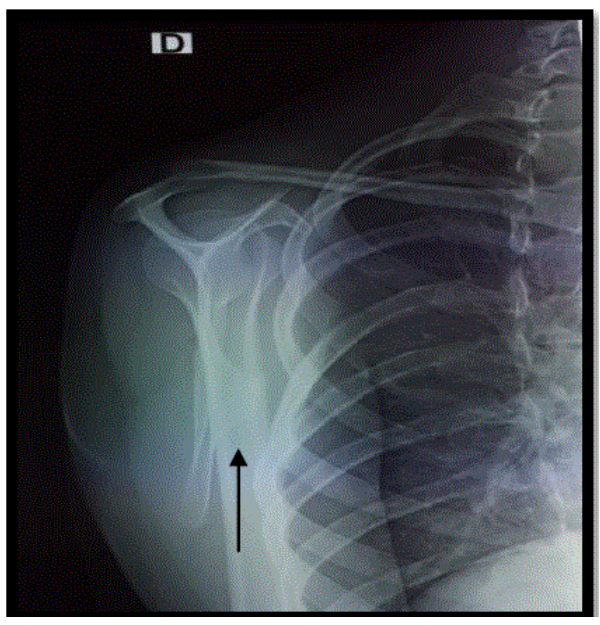

Figure 1. Shoulder profile, osteochondroma of the scapula.

\section{Discussion}

Osteochondroma or solitary exostosis is an hamartoma that develops during growth by enchondral ossification covered with a cartilaginous cap. It represents 20 to $50 \%$ of benign bone tumors and 10 to $15 \%$ of all bone tumors. Commonly located in long bones metaphysis around the knee of children and young adults with a male predilection [1].

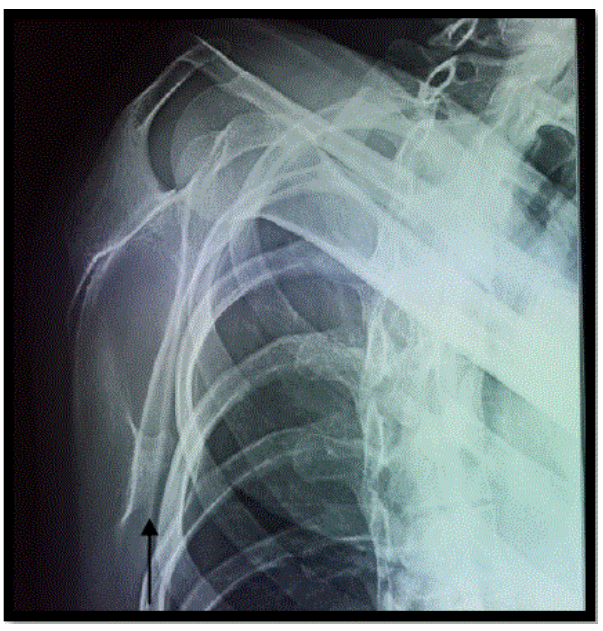

Figure 2. Profile of scapula showing exostosis of ventral side of scapula.

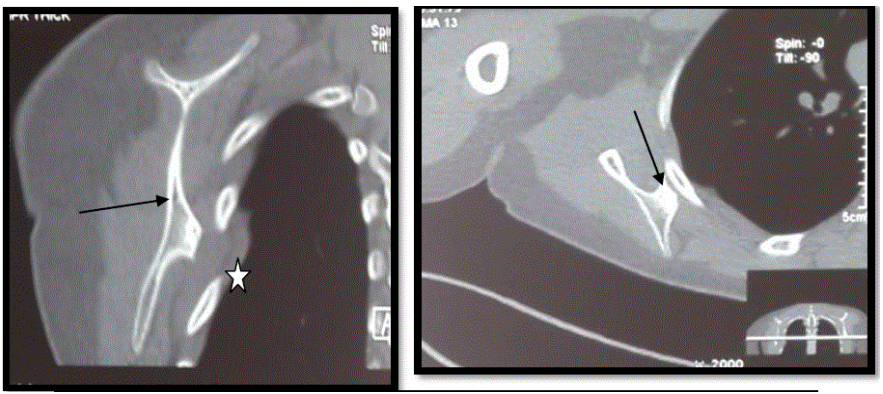

Figure 3. CT scan of scapula showing the exostosis of ventral side of scapula beneath the 4th rib with reactive pelural infusion.

Correspondence to: Sara El Rharras, Department of Rheumatology, Arrazi Hospital, Mohammed VI Universitary Center, Avenue Ibn Sina, Marrakech, Morocco, Tel: +212668174774; E-mail: saraelrharras@yahoo.fr

Received: June 24, 2017; Accepted: July 14, 2017; Published: July 17, 2017 


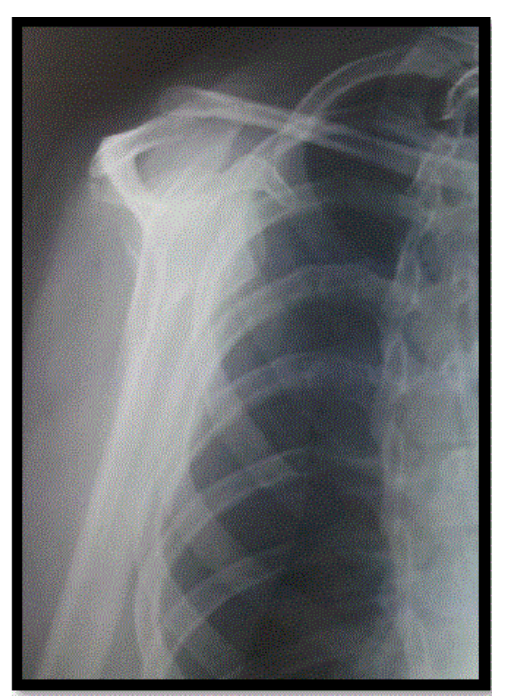

Figure 4. Shoulder profile after surgery, complete regression of the osteochondroma.

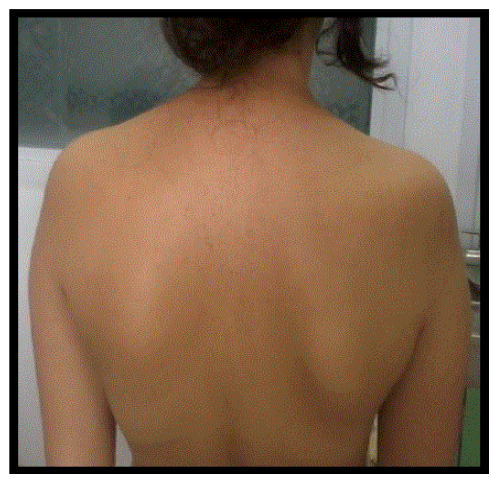

Figure 5. Before surgery: winging of right scapula at static postition.

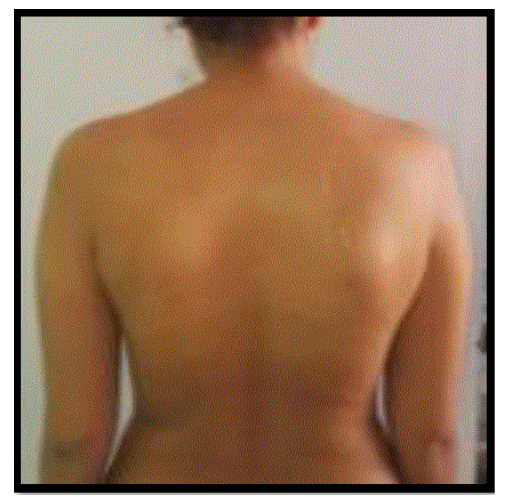

Figure 6. After surgery: regression of scapula winging.

Scapula location is uncommon, in approximately $3 \%$ of osteochondromas [2]. Mrad-Dali et al., reported 7 cases out of 95 cases [3]. About 45 cases were also published separately by different authors [4-18]. Ventral localization like our case was repoted in two cases [19].

Winging of the scapula can be either dynamic or static. Dynamic winging is due to neuromuscular disorders. The deformity is produced by active shoulder movements and is often absent at rest. Static winging is due to a fixed deformity in the shoulder girdle, spine, or ribs and is characteristically present at rest with the arm at the side [20-23]. The osteochondroma in this case report expanded the deep surface of the right scapula, showing the scapula away from the chest wall and producing static winging. Carlson et al. in a review of 89 cases of snapping scapula syndrome reported skeletal abnormalities in 11 cases. 27 cases were idiopathic and osteochondromas were seen in 3 cases [11]. Pseudo-winging of the scapula and scapular snapping are two clinical signs of upper girdle insufficiency. The association of these two signs is highly suggestive of exostosis of the ventral aspect of the scapula [24]. The radiological aspect of bone continuity between the exostosis and the cortical is pathognomonic of osteochondroma. Size increasing may leads to sarcomatous degeneration frequently observed in multiple exostosis disease with autosomal dominant transmission compared to solitary osteochondromas [25] . Surgical resection of the tumor is a reliable treatment for symptomatic forms [26-27]. The postoperative evolution is generally satisfactory, as shown by Ermis et al. and Sreenivas et al. [28-29].

\section{Conclusion}

Scapula is a rare localization of solitary osteochondroma. The diagnosis is based on the radiological and CT scan if possible. Surgical excision makes it possible to avoid the sarcomatous transformation. Long-term follow-up is advised to identify rare event of local recurrence or appearance of lesions in other sites.

\section{References}

1. Giudici MA1, Moser RP Jr, Kransdorf MJ (1993) Cartilaginous bone tumors. Radiol Clin North Am 31: 237-259. [Crossref]

2. Kumar N, Ramakrishman V, Johnson GV et al. Endoscopically assisted excision of scapular osteochondroma. Acta Orthop Scand 1999;70:394-6.

3. Mdimegh L, Zohd M, Ben Hmida R, et al. Ostéochondrome : a propos de 95 cas. OA-WS-37.

4. T. A. Parsons. The snapping scapula and subscapular exostoses. J Bone Joint Surg Am $1973 ; 55 \mathrm{~B}(2)$.

5. Hommadi A1, Ziadi T, Louaste J, Amhaji L, Drissi SM, et al. (2009) [Chondroma of the acromion: an unusual localization]. Chir Main 28: 120-122. [Crossref]

6. Fjeldborg PK, Hansen TB. Atypical cause of scapular winging due to exostosis of the scapula]. [Article in Danish] Laeger U . 2012; 174 (6): 354-5.

7. Orth P1, Anagnostakos K, Fritsch E, Kohn D, Madry H (2012) Static winging of the scapula caused by osteochondroma in adults: a case series. J Med Case Rep 6: 363 . [Crossref]

8. Nercessian O1, Denton JR (1988) Cartilaginous exostosis arising from the ventral surface of the scapula. A case report. Clin Orthop Relat Res : 145-147. [Crossref]

9. Ben Hamouda M1, Allegue M, Bergaoui N, Dahmene J, Korbi S, et al. (1993) [Scapular exostosis complicated by bursitis. Apropos of a case]. J Radiol 74: 143-146. [Crossref]

10. Than P1, Bálint L, Kustos T (1995) [The scapula: rare localization of osteochondroma]. Orv Hetil 136: 2047-2049. [Crossref]

11. Carlson HL, Haig AJ, Stewart DC. Snapping scapula syndrome: three case reports and an analysis of the literature. Arch Phys Med Rehabil. 1997; 78 (5): 506-11.

12. Flugstad NA, Sanger JR, Hackbarth DA. Pseudo-winging of the scapula caused by scapular osteochondroma: review of literature and case report. Hand (N Y). 2015; 10 (2): $353-6$.

13. Karabila MA1, Otmani L1, Azouz M1, Mhamdi Y1, Hmouri I1, et al. (2015) [Large osteochondroma of the scapula: report of a case]. Pan Afr Med J 22: 360. [Crossref]

14. Edelstein AI1, Linn RL, Fritsch MK, Sagan M (2015) Osteochondroma With Contiguous Bronchogenic Cyst of the Scapula. Am J Orthop (Belle Mead NJ) 44: E355357. [Crossref]

15. Sarikaya B, Suluova F, Cetin BV. Endoscopically Assisted Resection of a Rare Mass Intra-Articular Osteochondroma of Shoulder Originated from Scapula Case Rep Orthop. 2016: 7684807.

16. Jadhav PU, Banshelkikar SN, Seth BA, et al. Osteochondromas at Unusual Sites- Case Series with Review of Literature. J Orthop Case Rep. 2016 ; 6(1): 52-4 
17. Jindal M1 (2016) Delayed Presentation of Osteochondroma at Superior Angle of Scapula-A Case Report. J Orthop Case Rep 6: 32-34. [Crossref]

18. Nascimento AT, Claudio GK. Snapping scapula. Arthroscopic resection of osteochondroma of the subscapularis superomedial angle. Case report and literature review. Rev Bras Ortop. 2017, 5; 52 (2): 220-223.

19. Tittal P, Pawar I, Kapoor SK, et al. Pseudo-winging of scapula due to benign lesions of ventral surface of scapula - Two unusual causes. J Clin Orthop Trauma. 2015; 6 (1) $30-5$.

20. Bloch AM, Nevo Y, Ben-Sira L, Harel S, Shahar E. Winging of the scapula in a child with hereditary multiple exostoses. Pediatr Neurol. 2002; 26(1) :74-6.

21. Danielsson LG1, el-Haddad I (1989) Winged scapula due to osteochondroma. Report of 3 children. Acta Orthop Scand 60: 728-729. [Crossref]

22. Fiddian NJ, King RJ (1984) The winged scapula. Clin Orthop Relat Res : 228-236. [Crossref]

23. Rameez R, Ul-Hassan M1, Kotwal HA1, Kangoo KAH1, Nazir A1 (2016) Painful Pseudowinging and Snapping of Scapula due to Subscapular Osteochondroma: A Case Report. J Orthop Case Rep 6: 96-99. [Crossref]
24. Girard J, Laffargue P, Migaud H, et al. (2003) Scapula alata statique et accrochage scapulaire secondaires à une exostose solitaire. A propos de 2 cas. Revue de Chirurgie Orthopédique et Traumatologique 89: 449-452.

25. Blacksin MF, Benevenia J (2000) Neoplasms of the scapula. AJR Am J Roentgenol 174 1729-1735. [Crossref]

26. Kumar N, Ramakrishnan V, Johnson GV, Southern S (1999) Endoscopically-assisted excision of scapular osteochondroma. Acta Orthop Scand 70: 394-396. [Crossref]

27. Parsons TA (1973) The snapping scapula and subscapular exostoses. J Bone Joint Surg $\operatorname{Br} 55$ : 345-349. [Crossref]

28. Ermis MN, Aykut U, Durakbasa MO Ozel MS, Bozkuş FS, et al. (2012) Snapping scapula syndrome caused by subscapular osteochondroma. Eklem Hastalik Cerrahisi 23: 40-43. [Crossref]

29. Sreenivas T, Ravi Kumar N, Nataraj AR (2015) A retrospective analysis of osteochondroma of scapula following excision biopsy. Acta Orthop Belg 81: 303-307. [Crossref]

Copyright: (C2017 El rharras S. This is an open-access article distributed under the terms of the Creative Commons Attribution License, which permits unrestricted use, distribution, and reproduction in any medium, provided the original author and source are credited. 